\title{
Combination of AHP Method and VIKOR Method For Assesing Sunday School Teacher
}

\author{
Devi Valentino Waas*1, Suprapto ${ }^{2}$ \\ ${ }^{1}$ Master Program of Computer Science and Electronics, FMIPA, UGM, Yogyakarta Indonesia \\ ${ }^{2}$ Department of Computer Science and Electronics, FMIPA, UGM, Yogyakarta Indonesia \\ e-mail: ${ }^{* 1}$ valentinowaas30@gmail.com, ${ }^{2}$ sprapto@ ugm.ac.id
}

\begin{abstract}
Abstrak
Penilaian kinerja pengasuh pada Jemaat Imanuel Lurang bertujuan untuk mengukur dan membedakan kualitas kinerja yang telah dicapai oleh para pengasuh serta memutuskan berbagai kebijakan seperti pemberian reward kepada setiap pengasuh dengan kinerja terbaik, dan untuk pengasuh yang mempunyai nilai kinerja kurang baik akan dilakukan pendekatan pembimbingan dan lain sebagainya. Banyaknya kriteria dalam menentukan kualitas pengasuh bukanlah merupakan suatu hal yang mudah apalagi jika dilakukan secara manual. Maka sangat dibutuhkan sebuah sistem aplikasi penilaian kinerja yang berbasis komputerisasi untuk dapat mempercepat proses penilaian yang sedang berjalan agar menjadi lebih efektif dan efisien.

Penelitian ini mengembangkan sistem pendukung pengambilan keputusan (SPPK) bersifat dinamis menggunakan bahasa pemrograman PHP, dengan mengombinasikan metode AHP yang sudah disempurnakan dengan metode VIKOR. Metode AHP digunakan dalam penentuan bobot setiap kriteria, dan metode VIKOR digunakan untuk proses perengkingan.

Hasil pengujian menunjukkan bahwa sistem dapat memberikan urutan alternatif pengasuh yang akan dijadikan rekomendasi bagi pengambil keputusan untuk menentukan mana pengasuh yang berkualitas dan tidak berkualitas.
\end{abstract}

Kata kunci-SPPK, AHP, VIKOR,Penilaian Kinerja Pengasuh

\begin{abstract}
The performance appraisal of Sunday school teacher in the Imanuel Lurang congregation aims to measure and distinguish the quality of performance achieved by Sunday school teacher and decide various policies such as giving rewards to every Sunday school teacher with the best performance, and for Sunday school teacher who have poor performance scores will be given a guiding, approach, etc. The number of criteria in determining the quality of Sunday school teacher is not an easy thing to do by manual. Then it is essential that a computerized performance appraisal-based performance app can speed up the process of progressing to be more effective and efficient.

This research develops decision support systems (DSS) that is dynamic using the PHP programming language, by combining the AHP method that has been refined by the VIKOR method. The AHP method is used in determining the weight of each criterion, and the VIKOR method is used for the ranking process.

Test results indicate that the system can provide a sequence of alternative Sunday school teacher that will be used as recommendations for decision makers to determine which Sunday school teachers are quality and not qualified.
\end{abstract}

Keywords-DSS, AHP, VIKOR, Assesment of Sunday School teacher performance 


\section{INTRODUCTION}

Performance appraisal means evaluating an employee's current and/or past performance relative to his/her performance standars [1]. Performance appraisal is expected to be able to act as a driving force and encouragement for employees to demonstrate optimal skills and expertise. Performance appraisal can measure and differentiate performance achievements that have been achieved by employees and decide various policies in the field of other human resources such as adjustment of rewards, training and development, promotion, promotion, class positions and so on [2]

Determination of the Sunday school teacher performance in the Immanuel GPM Congregation is less done by the Leader of the Assembly of the congregation or pastor. The number of criteria in determining the quality of Sunday school teaceher is not an easy thing especially if done manually, of course, it can lead to ineffectiveness and inefficiency in the implementation of the assessment. So it is very necessary a computerized performance appraisal application system to be able to accelerate the ongoing assessment process to be more effective and efficient.

Multi-Criteria Decision Making (MCDM) is a decision-making method to determine the best alternative from a alternatives number based on several predetermined criteria. MCDM is concerned with structuring and solving decision and planning problems involving multiple criteria. The purpose is to support decision makers facing such problems. Typically, there does not exist a unique optimal solution for such problem and it is necessary to use decision maker's preferences between solutions [3].

The MCDM method proposed in this study is a combination of AHP method with the VIKOR method. The combination of these two methods was chosen because each has its own advantages. The AHP method has advantages in the weighting stage of the criteria with the consistency test to see whether the weight obtained is consistent. Whereas the VIKOR method has a deficiency in the weighting stage, the weighting process is only given away by the boss without checking the weighting consistency. Conversely, the AHP method has a deficiency in the cracking process. The AHP cracking process becomes more complex with increasing iterations if more and more alternatives. Whereas, the VIKOR method has advantages in the cracking process by having preference values for cracking and can easily overcome the multiple alternatives [4].

\subsection{Process Design}

\section{METHODS}

Assessment process of caregiver performance is shown in Figure 1. The caregiver performance of assessment process is carried out by combining the AHP method with the VIKOR method. Both of these methods are used because each has its own advantages. AHP method is used in the criteria weighting process, while the VIKOR method is used in the cracking process.

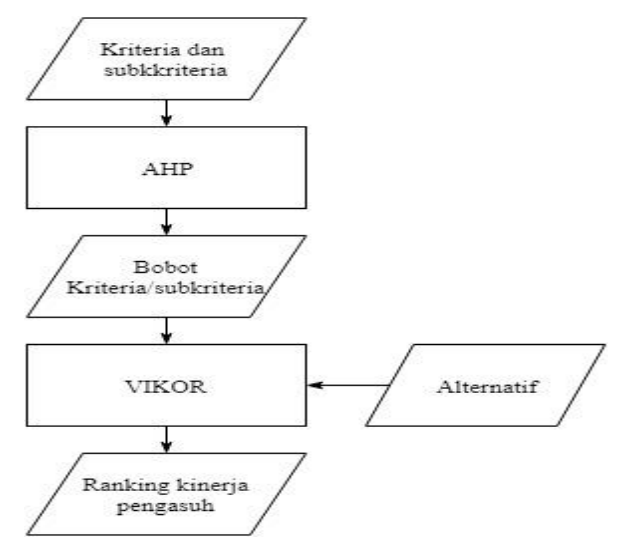

Figure 1. Process Design

IJCCS Vol. 14, No. 1, January 2020 : $45-56$ 


\subsubsection{Analysis of System Structure}

The system designed in this study is a system that can provide an assessment of the caregiver's performance in the Immanuel Church, Lurang Village. The data needed in this study are alternative data, criteria data, and subcriteria data. In this study using 7 criteria and 30 subcriteria shown in table 1.

Table 1 Criteria and assessment sub-criteria

\begin{tabular}{|c|c|c|}
\hline NO & Criteria & Sub-criteria \\
\hline \multirow[t]{4}{*}{1} & Loyalty & Basic Service according to the teachings of the Bible \\
\hline & & Hold on to the promises \\
\hline & & Do not change \\
\hline & & Do not complaints \\
\hline \multirow[t]{4}{*}{2} & Responsibility & Responsibility for God \\
\hline & & Responsibility for self and family \\
\hline & & Responsibility for the Church \\
\hline & & Responsibility for assignments and calls as caregivers. \\
\hline \multirow[t]{4}{*}{3} & Discipline & Attendance \\
\hline & & Working time \\
\hline & & Obedience \\
\hline & & Dress code \\
\hline \multirow[t]{5}{*}{4} & Obedience & Obedience to the rules set by the Church \\
\hline & & Implementing regulations in daily life \\
\hline & & Work based on the job description given \\
\hline & & Respect local customs/culture \\
\hline & & Keep Words \\
\hline \multirow[t]{4}{*}{5} & Cooperation & Cooperation between caregivers \\
\hline & & Cooperation with other service areas. \\
\hline & & Become an active member in several church organizations. \\
\hline & & Mutual trust and mutual support \\
\hline \multirow[t]{4}{*}{6} & Achievement & Initiative \\
\hline & & Perform and complete tasks and responsibilities \\
\hline & & Decision to deal with an emergency situation \\
\hline & & Mastery of material \\
\hline \multirow[t]{5}{*}{7} & Leadership & Decision making and realizing the decision \\
\hline & & Motivate \\
\hline & & Coordination \\
\hline & & Organizational development and development \\
\hline & & Accountability \\
\hline
\end{tabular}

The system architecture used in the caregiver performance appraisal system is a relationship that can be seen between the components related to the system. The system architecture can be seen in Figure 2 below 


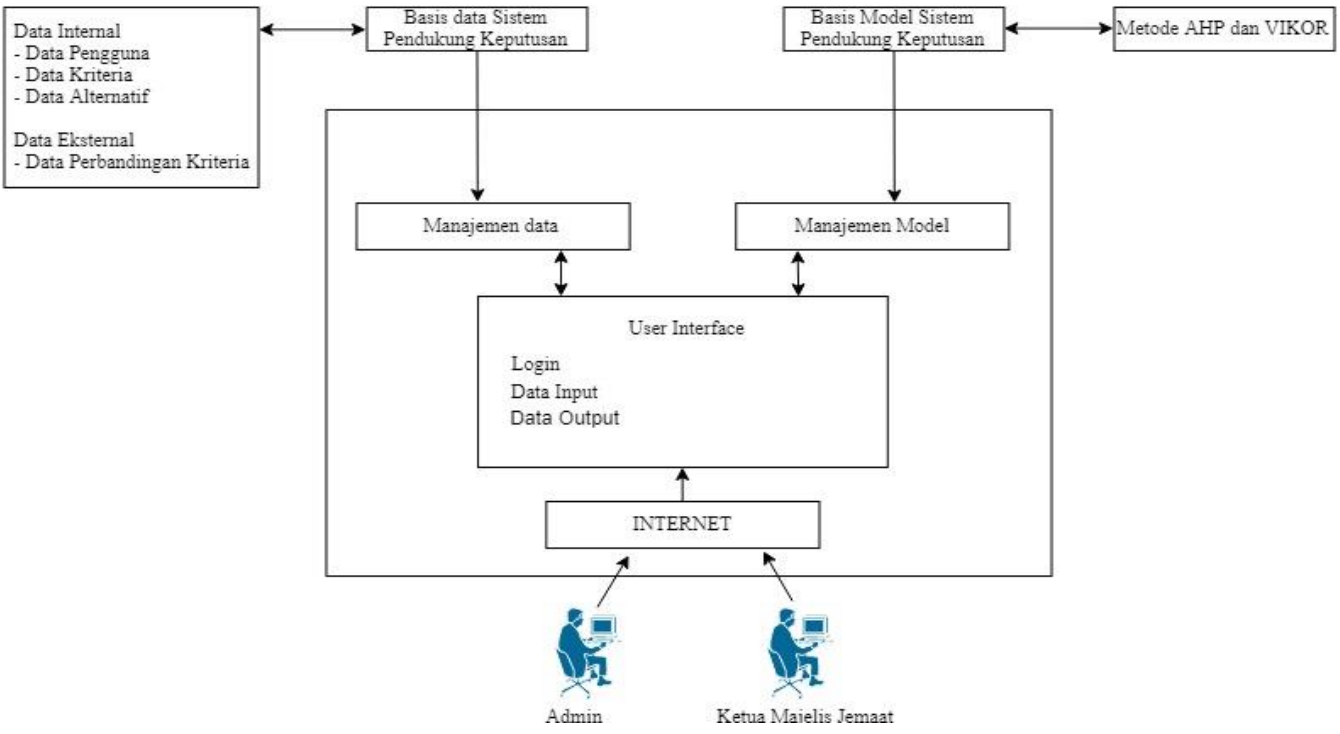

Figure 2 Architecture of the caregiver performance assessment system

\subsection{Analithycal Hierarchy Process (AHP)}

The AHP method was introduced by Dr. Thomas Saaty from the Wharton School of Business in 1970 to organize information and assessment in choosing the most preferred alternative [5]. According to Saaty, AHP is a method aimed at solving complex and unstructured problems, where the criteria or aspects that affect the unstructured problem, uncertainty of decision-making perception or lack of sufficient data/information. With a hierarchy, a complex and unstructured problem is divided into groups and then the group is organized into a hierarchical form [6]. problems:

The working principle in the AHP method that needs to be understood in solving

a. Decomposition (hierarchical arrangement)

Decomposition is the process of analyzing real problems into a hierarchical structure of the supporting elements. In general, the hierarchy consists of three levels: the first level is the decision goal (goal), the second level consists of criteria and sub-criteria (optional) and the third level is the alternative solutions offered. The hierarchical arrangement is shown in Figure 3.

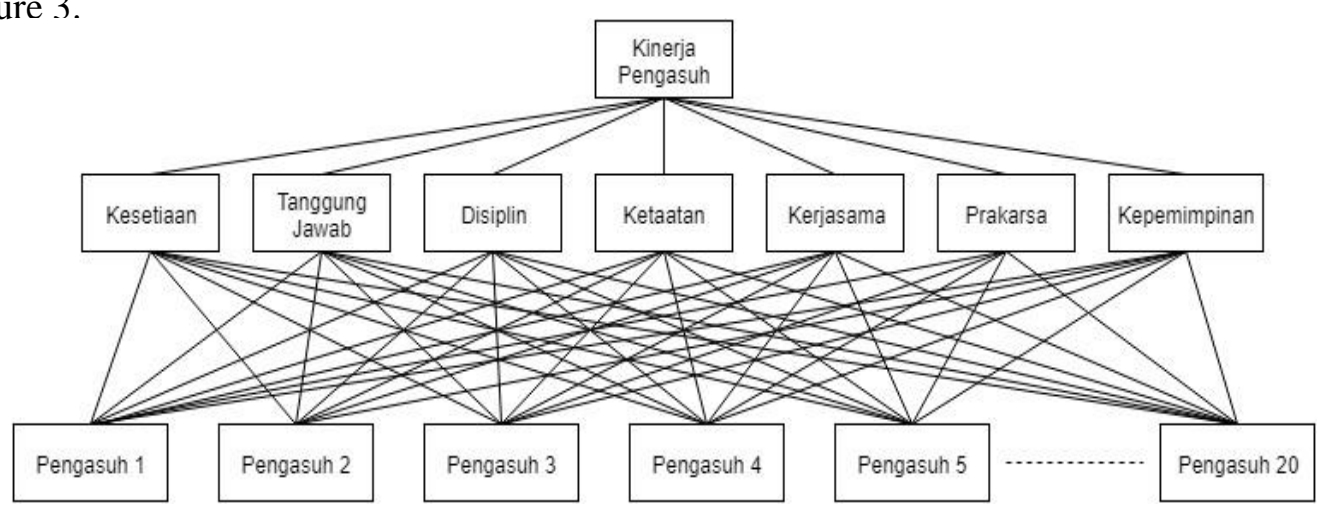

Figure 3 Hierarchical of AHP [5]

b. Pairwise Comparison Matrix.

Pairwise comparisons aim to make an assessment of the importance between two elements at a certain level which is presented in the form of a matrix with a priority scale. If there are $n$

IJCCS Vol. 14, No. 1, January 2020: $45-56$ 
elements, a matrix measuring $n \times n$ and the number of judgments needed is $n(n-1) / 2$. The assessment of the pairwise comparison matrix element is shown in equation (1)

$A$

$$
=\left[\begin{array}{cccc}
1 & a_{12} & \cdots & a_{1 n} \\
a_{21} & 1 & \cdots & a_{2 n} \\
\vdots & \vdots & \ddots & \vdots \\
a_{n 1} & a_{n 2} & \cdots & 1
\end{array}\right] \sim\left[\begin{array}{cccc}
1 & a_{12} & & \\
\frac{1}{a_{21}} & 1 & \cdots & a_{1 n} \\
\vdots & 1 & \ddots & a_{2 n} \\
\frac{1}{a_{n 1}} & \frac{1}{a_{n 2}} & \cdots & 1
\end{array}\right]
$$

Where:

$A \quad$ : Pairwise comparison matrix

$a_{i j} \quad$ : The assessment of the importance of the criteria for $i$-th compared to the $j$-th criteria.

$i, j \quad: 1 \ldots n$ is the number of criteria

To assess the comparison of the importance of one element to another element using the Saaty scale, starting from weights 1 to 9 are shown in Table 2 .

Table 2 Interest Scale

\begin{tabular}{|c|l|l|}
\hline Value & \multicolumn{1}{|c|}{ Importance } & \multicolumn{1}{c|}{ Explanation } \\
\hline 1 & $\begin{array}{l}\text { Both elements are equally } \\
\text { important }\end{array}$ & $\begin{array}{l}\text { Two elements have the same effect on the } \\
\text { goal }\end{array}$ \\
\hline 3 & $\begin{array}{l}\text { One element is more important } \\
\text { than the other }\end{array}$ & $\begin{array}{l}\text { Experience and assessment slightly support } \\
\text { one element compared to other elements }\end{array}$ \\
\hline 5 & $\begin{array}{l}\text { One element is more } \\
\text { important than the other }\end{array}$ & $\begin{array}{l}\text { Experience and judgment strongly support } \\
\text { one element compared to another }\end{array}$ \\
\hline 9 & $\begin{array}{l}\text { One element is clearly more } \\
\text { absolute more important than } \\
\text { other elements }\end{array}$ & $\begin{array}{l}\text { A strong element is supported and dominant } \\
\text { seen in practice }\end{array}$ \\
\hline $2,4,6,8$ & $\begin{array}{l}\text { One element is absolutely } \\
\text { important than other elements }\end{array}$ & $\begin{array}{l}\text { Evidence that supports one element against } \\
\text { another has the highest level of affirmation } \\
\text { that might strengthen }\end{array}$ \\
\hline Opposite \\
consideration values
\end{tabular}$\quad \begin{aligned} & \text { If for criteria } i \text { gets one number compared to criterion } j \text {, then } j \text { has the } \\
& \text { compromises between two choices } \\
& \text { opposite value compared to } i\end{aligned}$

c. Priority determination

After the pairwise comparison matrix is created, the next step is to measure the priority weights of each element. The end result of this calculation is a decimal number below one (for example 0.01 to 0.99 ) with a total priority for elements in one group equal to one.

Determination of priority weights using geometric averages, in the way:

1. Multiplying the value of each row and calculating the $n$-th root of product in equation (2).

$$
\bar{w}_{i}=\sqrt[n]{\prod_{j=1}^{n} a_{i j}}
$$

Where:

$\bar{w} \quad$ : the $i$-normalized weighting criteria

$a_{i j} \quad:$ assessment of the importance of the $i$-factor compared to the $j$-th factor

$i \quad: 1 \ldots \mathrm{n}$ is the number of criteria

2. Normalize the root to get the weight (eigen vector) in equation(3). 


$$
w_{i}=\frac{\bar{w}}{\sum_{i=1}^{n} \bar{w}_{i}}
$$

Where :

d. Logically consistent

$$
w_{i} \quad \text { : normalized i-weight criteria (eigen vector) }
$$

One of the main assumptions of the AHP method that distinguishes it from other methods is the absence of absolute consistency requirements. Based on this condition, decisionmakers can express their perceptions freely without having to think about whether the perception will be consistent later or not. The Consistency Ratio (CR) tells decision makers how consistent it is when doing pairwise comparisons.

To measure CR, the following methods are carried out:

1. The values contained in the pairwise comparison matrix are summed, and the number is multiplied by each normalized weight

2. Then the weight value is summed, this value is recognized by lambda max (maximum eigen value)

3. Check Consistency Index $(\mathrm{CI})$ in equation (4)

$$
\begin{aligned}
& C I=\frac{\lambda_{\text {maks }}-n}{n-1} \\
& \text { Where: } \\
& \text { CI : Consistency Index } \\
& \lambda_{\text {maks }}: \text { maximum eigen value } \\
& n \quad \text { : amount of criteria }
\end{aligned}
$$

4. Calculate and check Consistency Ratio (CR) in equation (5).

$$
\begin{array}{ll}
\multicolumn{1}{c}{C R=\frac{C I}{R I}} \\
\text { Where: } \\
C R \quad \text { : Consistency Ratio } \\
C I \quad: \text { Consistency Index } \\
R I \quad: \text { Index Random Consistency }
\end{array}
$$

If the $\mathrm{CR}$ value is $<0.1$ then it can be said that the pairwise comparison matrix made is consistent. But if the value is more than 0.1 then the criteria assessment must be corrected.

e. Determination of global priorities

At this stage, the index ratio (IR) will be determined. The IR value used uses the equation in the Alonso and Lamata study [7] which can handle more than 15 criteria.

the equation to get the IR value, which is as follows:

$$
\begin{aligned}
& I R=\frac{\bar{\lambda} \max -n}{n-1} \\
& \bar{\lambda} \max =2.7699 n-4.3513
\end{aligned}
$$

After getting the IR value, then find the ratio of weighting consistency or (CR) using equation (5). If $C I=0$ then matrix A is consistent, if $C I / I R \leq 0.1$ then matrix A is quite consistent, and if $C I / I R>$ 0.1 then matrix $\mathrm{A}$ is very inconsistent

\subsection{VIKOR method (VIsekriterijumsko KOmpromisno Rangiranje)}

VIKOR is a Multi-Criteria Decision Making (MCDM) method which was first developed by Opricovic and Tzeng [8]. The focus of the VIKOR method is to make clashes and choose solutions from a set of alternatives in circumstances where the reference criteria are contradictory [9]. As for the crackdown on alternative solutions based on a measure of proximity to the ideal solution.

The procedure for calculating the VIKOR method is according to [10] and [11] follows the steps below:

IJCCS Vol. 14, No. 1, January 2020 : $45-56$ 
1. Develop criteria and alternatives in the form of a matrix

At this stage each criterion and alternative are arranged in the form of a matrix $\mathrm{F}$, Ai states the alternative to $i$, with $i=1,2,3, \ldots, m$ and $\mathrm{Cj}$ are the $\mathrm{j}$ criteria, with $\mathrm{j}=1,2,3, \ldots, \mathrm{n}$

$$
F=\begin{array}{cccc}
C_{1} & C_{2} & \cdots & C_{n} \\
A_{1} \\
A_{2} \\
\vdots \\
A_{m}
\end{array}\left[\begin{array}{cccc}
x_{11} & x_{12} & \cdots & x_{1 n} \\
x_{21} & x_{22} & \cdots & x_{2 n} \\
\vdots & \vdots & \vdots & \vdots \\
x_{m 1} & x_{m 2} & \cdots & x_{m n}
\end{array}\right]
$$

2. Calculate the normalization of the decision matrix

Calculation of the normalization of the decision matrix for each data $X_{i j}$ follows equation (9).

$$
\begin{aligned}
f_{i j}= & \frac{x_{i j}}{\sqrt{\sum_{j=1}^{n} x_{i j}^{2}}}, i=1,2, \ldots, m ; j=1,2, \ldots, n \\
\text { Where: } & \\
& x_{i j} \quad: \text { The value of each attribute to the criteria } \\
& f_{i j} \quad: \text { Normalized value. } \\
m & : \text { The } m \text {-th alternative } \\
n & : n \text {-th criteria }
\end{aligned}
$$

A matrix $\mathrm{F}$ will be obtained which contains the overall value of the normalized element, shown in equation (10)

$$
F=\left[\begin{array}{ccc}
f_{11} & \cdots & f_{1 n} \\
\vdots & \ddots & \vdots \\
f_{m 1} & \cdots & f_{m n}
\end{array}\right]
$$

3. Determine the best value $\left(f_{j}^{*}\right)$ and worst value $\left(f_{j}^{-}\right)$against each criterion. $f_{j}^{*}$ is a positive ideal solution for the $j$-th criteria, while $f_{j}^{-}$is a negative ideal solution for the $j$-th criteria.

Criteria that have higher values, the more optimal is the benefit criteria, while the criteria that have lower value, the more optimal is the cost criterion.

Determination of values $f_{j}^{*}$ and $f_{j}^{-}$of all criterion functions carried out in succession through equations (11) and (12).

For the benefit criteria function:

$$
f_{j}^{*}=\max _{i} f_{i j}, \quad f_{j}^{-}=\min _{i} f_{i j}
$$

For the cost criteria function:

$$
f_{j}^{*}=\min _{i} f_{i j}, \quad f_{j}^{-}=\max _{i} f_{i j}
$$

4. Calculate the value of Utility Measures

To get the utility measures value, we need criteria weight value $\left(w_{j}\right)$. Criteria weighting aims to represent relative interests. Utility measures of each alternative are calculated using equations (13) and (14).

$$
\begin{aligned}
& S_{i}=\sum_{i=1}^{n} w_{j} \frac{\left(f_{j}^{*}-f_{i j}\right)}{\left(f_{j}^{*}-f_{j}^{-}\right)} \\
& R_{i}=\max _{j}\left[w_{j} \frac{\left(f_{j}^{*}-f_{i j}\right)}{\left(f_{j}^{*}-f_{j}^{-}\right)}\right]
\end{aligned}
$$


$S_{i}$ (maximum group utility) and $R_{i}$ (minimum individual regret of the opponent), both state that utility measures are measured from the farthest point and the closest point of the ideal solution.

Information:

$S_{i} \quad:$ Alternative distance values to positive ideal solutions

$R_{i} \quad$ : Alternative distance values to negative ideal solutions

$w_{j} \quad:$ The weight value obtained from the calculation in equation (3)

5. Calculate VIKOR Value $\left(Q_{i}\right)$

Equation (15) describes the process of obtaining VIKOR values for each alternative caregiver performance. To calculate the value of VIKOR, variable $\mathrm{v}$ is known as the strategic weight of the majority of the criteria, where the value $\mathrm{v}$ is between $0-1$ (generally worth 0.5$)$. The smaller the VIKOR index value, the better the alternative solution.

$$
Q_{i}=v \frac{\left(S_{i}-S^{*}\right)}{S^{-}-S^{*}}+(1-v) \frac{\left(R_{i}-R^{*}\right)}{\left(R^{-}-R^{*}\right)}
$$

Information:

$S^{*}: \min _{i} S_{i}$ (The smallest value of the alternative)

$S^{-}: \max _{i} S_{i}$ (The biggest value of alternatives)

$R^{*}: \min _{i} R_{i}$ (The smallest value of the alternative)

$R^{-}: \max _{i} R_{i}$ (The biggest value of alternatives)

$v$ : representation of the weight value that ranges from 0-1 (generally worth 0.5 )

\section{RESULTS AND DISCUSSION}

In this section, the results of the test will be shown on the caregiver's performance assessment system. This test aims to show whether the system has been fulfilled or not, both in the process and the results provided.

\subsection{Testing data input}

Input criteria and sub-criteria data

Data input testing aims to test whether the process of inputting data in the system runs according to the design or not. Figures 4 and 5 show the inputting criteria and the results of input for each assessment criterion.

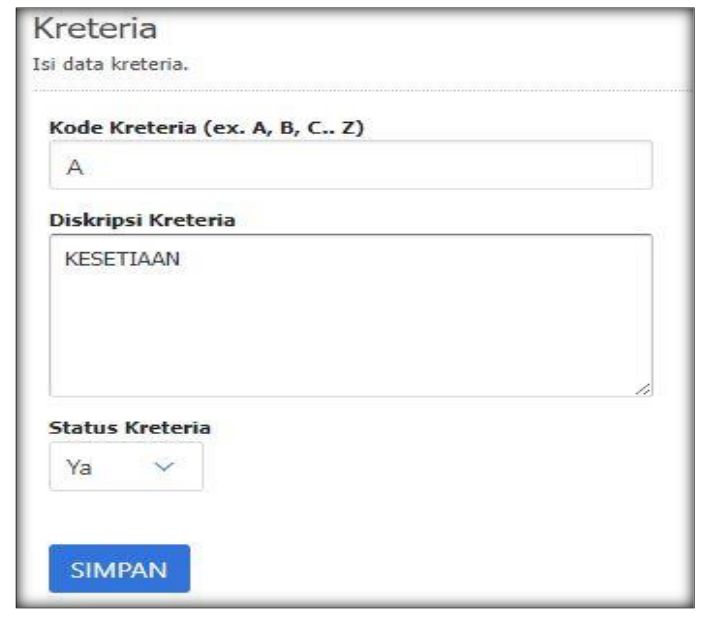

Figure 4. Input criteria data

IJCCS Vol. 14, No. 1, January 2020 : $45-56$ 


\begin{tabular}{|l|l|l|l|l|l|l|}
\hline + Kreteria Baru & $\oplus$ Bobot Kreteria & Bobot Semua Sub Kreteria \\
\hline No & Kode & Diskripsi & Status & AKSI & \\
\hline 1 & A & KESETIAAN & Aktif & Ubah & Hapus & Sub Kreteria \\
\hline 2 & B & Prestasi dan Tanggung Jawab & Aktif & Ubah & Hapus & Sub Kreteria \\
\hline 3 & C & DISIPLIN & Aktif & Ubah & Hapus & Sub Kreteria \\
\hline 4 & D & KETAATAN & Aktif & Ubah & Hapus & Sub Kreteria \\
\hline 5 & E & KERISAMA & Aktif & Ubah & Hapus & Sub Kreteria \\
\hline 6 & F & PRAKARSA & Aktif & Ubah & Hapus & Sub Kreteria \\
\hline 7 & G & KEPEMIMPINAN & Aktif & Ubah & Hapus & Sub Kreteria \\
\hline
\end{tabular}

Figure 5. Results of input criteria

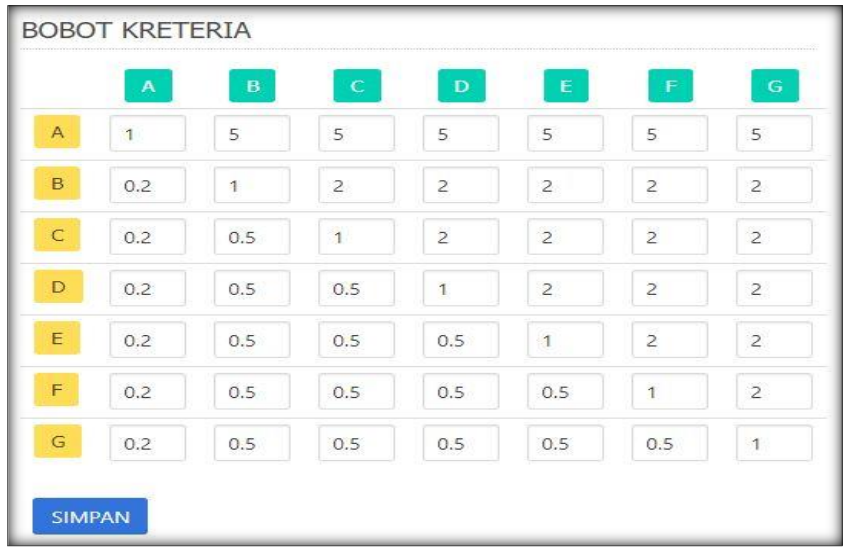

Figure 6. Input criteria weight

Alternative data input

In inputting alternative data and alternative values, the admin and user have the same access rights. An example of alternative input is shown in Figure 7, the input of the alternative value is shown in figure 8 , and the results of alternative input are shown in figure 9 .

\begin{tabular}{|l|}
\hline Data Alternatif \\
ID Alternatif \\
AL01 \\
Nama Alternatif \\
David \\
Status Aktif \\
\hline Ya $\checkmark$ \\
\hline \\
SIMPAN \\
\hline
\end{tabular}

Figure 7. Alternative data input 


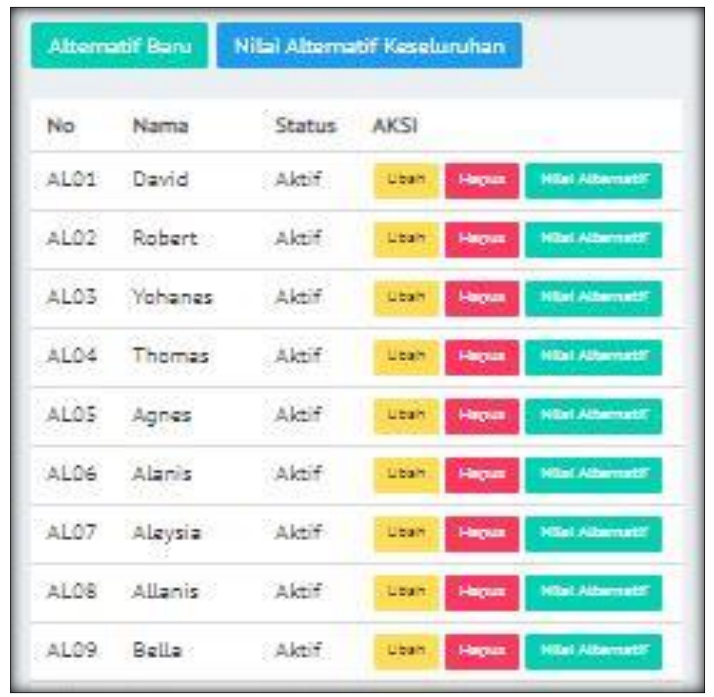

Figure 8. Results of alternative data input

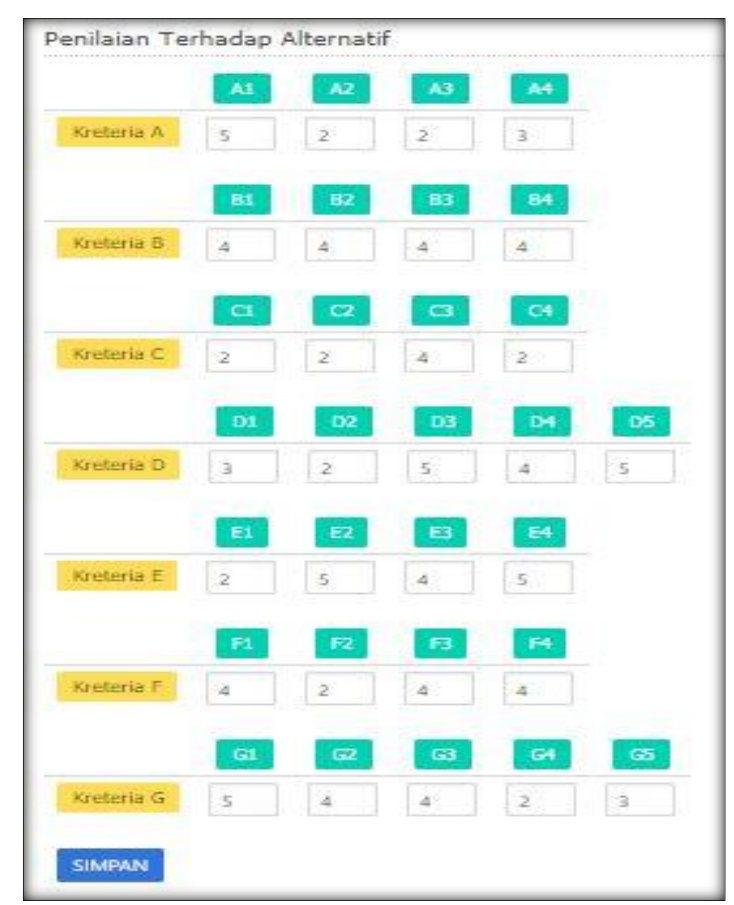

Figure 9. Input of alternative values

\subsection{Testing the results of calculations}

In the process of testing the results of the calculation, the comparison of the results of calculations manually and systemically will be carried out. Test results manually using Ms. tools. Excel is compared to the calculation results of the system. 


\begin{tabular}{|c|c|c|c|c|c|c|c|c|c|c|c|c|c|c|c|c|c|c|c|c|}
\hline & Not & Al02 & R.03 & ALC & ALO5 & $M 106$ & NOO & $\mathrm{NAOO}$ & N 169 & A.10 & AL11 & AL12 & AL13 & N14 & ㅅ15 & AL16 & AL17 & AL18 & AL19 & $A 120$ \\
\hline $\begin{array}{l}\text { Nama } \\
\text { Nerrad }\end{array}$ & Davio & Anest: & Yotunes & Thoras & Astes & Aanis & Atygh & Allenis & Betlo & crisso & Onistabel & Ourlet & Colesthune & Falitis & Filberts & Gerarts & Betilds & Eurwen & Biances & Berbi \\
\hline Rentim & 19 & 10 & 9 & 13 & 1 & 2 & 16 & 20 & 5 & 17 & 14 & 15 & 6 & 13 & 4 & 12 & 8 & 3 & 7 & 11 \\
\hline
\end{tabular}

Figure 10. results of system calculations

Table 3 Calculation results manually

\begin{tabular}{|r|r|r|}
\hline Alternatif & QI & RANK \\
\hline P1 & 0,914 & 19 \\
\hline P2 & 0,386 & 10 \\
\hline P3 & 0,221 & 9 \\
\hline P4 & 0,882 & 18 \\
\hline P5 & 0,000 & 1 \\
\hline P6 & 0,044 & 2 \\
\hline P7 & 0,763 & 16 \\
\hline P8 & 0,985 & 20 \\
\hline P9 & 0,163 & 5 \\
\hline P10 & 0,876 & 17 \\
\hline P11 & 0,623 & 14 \\
\hline P12 & 0,701 & 15 \\
\hline P13 & 0,165 & 6 \\
\hline P14 & 0,417 & 13 \\
\hline P15 & 0,134 & 4 \\
\hline P16 & 0,413 & 12 \\
\hline P17 & 0,217 & 8 \\
\hline P18 & 0,108 & 3 \\
\hline P19 & 0,170 & 7 \\
\hline P20 & 0,391 & 11 \\
\hline & & \\
\hline
\end{tabular}

Based on table 3 and figure 10, shows that the results of the calculation of the performance appraisal manually and the results of the calculation of the system give the same results and sequencing.

\section{CONCLUSIONS}

Based on the results of the research and discussion that has been carried out, it can be concluded that the caregiver's performance appraisal system can help the Church produce a caregiver ranking that can be used as recommendations in decision making. This is dynamic, so changes can be made at any time, adding even deletion of criteria and subcriteria data and alternative data.

From the results of the research, there are several things that need to be considered for the future development of this research, namely: the determination of criteria weight can be done using other methods, and for performance assessment can use a combination of other SPK methods, so the results can be compared with the AHP-VIKOR method. 


\section{REFERENCES}

[1] G. Desler, "Human Resource Management," 13th edition. London: Pearson Prentice Hall Inc. 2013.

[2] A. Tziner and E. Rabenu, "Improving performance appraisal at work," Edward Edgar Publishing. USA, 2018.

[3] M. Majumder, "Impact of Urbanization on Water Shortage in Face of Climatic Aberrations", SpringerBriefs in Water science and Technology, January 2015.

[4] S. Lengkong, "Sistem pendukung keputusan dinamis untuk seleksi penerima beasiswa menggunakan kombinasi metode AHP dan VIKOR," Tesis, Universitas Gadjah Mada, Yogyakarta. 2015.

[5] L. Hua and Q. Fei, "Analytic Hierarchy Process based judgement model og highly cited papers in journal" 2017 IEEE 2nd International Conference on Big Data Analysis (ICBDA), Oct 2017.

[6] T. L. Saaty and L. G. Vargas, "Models, Methods, Concepts and Applications of the Analytic Hierarchy Process", Second Edi., vol 175. Boston, MA: Springer US. 2012.

[7] J. A. Alonso and M. T. Lamata, "Consistency in the analytic hierarchy process: a new approach”, Int. J. Uncertainty, Fuzziness Knowledge-Based Syst., vol. 14, no. 4, pp. 445459. 2006.

[8] H. Liao and Z. Xu, "A VIKOR- based method for hesitant fuzzy multi -criteria decision making" SpringerLink volume 12, issue 4, pp 373-392, Dec 2018.

[9] P. Chatterjee and S. Chakraborty, "A Comparative analysis of VIKOR method and its variants", Decision Science Letters, Mey 2016

[10] A. Civic and B. Vucijak, "Multi-criteria optimization of insulation options for warmth of buildings to increase energy efficiency, " Procedia Eng., vol 69, pp. 911-920, 2014.

[11] X. Zhang, J. Jiang, B. Ge and K. Yang, "Group decision making for weapon systems selection with VIKOR based on consistency analysis", Systems Conference (SysCon) 2016 Annual IEEE, 1-6. 2016. 